\title{
Editorial
}

\section{Bynum Prize 2015}

The 2015 Medical History William Bynum Prize attracted a strong field of 12 entries, of which at least half are clearly of publishable quality. The four-person committee deliberated carefully on the essays. A small cluster stood out, necessitating a second round of deliberations. First prize was awarded to the essay by Lori Jones of the University of Ottawa, entitled 'When Medical Texts Double as Socio-Political Commentary: Exploring Some Other Contexts and Purposes of English Plague Treatises'. This explored with great skill and subtlety the wider contexts of these treatises in the Mediaeval and Early Modern Period. It examines the religious and professional background of the authors and the language they used. However, the Committee believed that an Honourable Mention should also be awarded to the essay, 'Internationalism and Colonialism in Conflict? The Politics of Nutrition in Fiji 1945-1965', by Sarah Hartley of the University of York, UK. There was little to separate these two fine essays, on very different topics and exploring different sets of materials.

The Committee, which consisted of Professor Colin Jones, Professor Amarjit Kaur, Dr Sue Heydon and Dr Philip Havik, wishes to place on record the high quality of the entries, which speaks well for the vigour of the field. 